\title{
Corporate Social Capital, Market Orientation, Organizational Learning and Service Innovation Performance: An Empirical Survey in the Pearl River Delta of China
}

\author{
Zhao Quan Jian, Yu Lu Zhou \\ School of Business Administration, South China University of Technology (China) \\ zqjian@scut.edu.cn, zhouyulu0212@163.com
}

Received: November 2014

Accepted: January 2015

\section{Abstract:}

Purpose: Service innovation performance (SIP) is an important driver of growth and wealth of service firms in wide range of industries. Yet, few researches have been done to explore its influencing factors. The purpose of this paper intends to identify the impacts of corporate social capital, market orientation and organizational learning on service innovation in the Pearl River Delta of China.

Design/methodology/approach: The paper mainly adopted the empirical research. A Structure Equation Model containing an intermediary variable was established to explore the relationships of SIP.

Findings: The main findings of the research support some of the propositions: (1) Both corporate social capital, market orientation and organizational learning have distinct positive impact on service innovation performance; (2) Corporate social capital, market orientation has a positive effect on organizational learning respectively, and (3) organizational learning plays a mediating role between the corporate social capital, market orientation and service innovation performance. 
Research limitations/implications: The research object of this paper has been restricted to the enterprises in Pearl River Delta of China. By contrast, variables and theories all come from western research, which was not adequate in explaining some results in the context of China. Given the limited theoretical and empirical research to service innovation, future research studies might widen their examinations scope to include other potential factors.

Originality/value: The insights from this paper can help service managers to better understand the relationship among corporate social capital, market orientation, organizational learning and service innovation performance in the context of China's economic transformation, as well as providing some useful guidance for the service sector's innovation activities.

Keywords: Corporate Social Capital (CSC), Market Orientation (MO), Organizational Learning (OL), Service Innovation Performance (SIP)

\section{Introduction}

Currently, developed countries are in the post-industrial era which is mainly characterized by massive production and consumption of services. Services have become an indispensible element in modern economies, where these activities are generally acknowledged in the process of social and economic development. Global economy is transitioning from goods or product-oriented to service or solution-oriented (Chesbrough, 2003). It is the service industries rather than manufacturing that becomes the source of new growth for regional productivity. An often restated argument is that service innovation has been increasingly recognized as an effective way to improve the service to create economic growth and welfare, particularly where labor costs or land prices are high. Thus, the inquiry of service innovation performance is significant from diverse service-oriented perspectives.

Not unexpectedly, the mechanisms governing the integration of the essential productive factors have been an area of intense investigation and the use of social capital management has provided a powerful tool for corporations to obtain core competitiveness in the networked society. Corporate social capital is considered as a key strategic resource of social network in human economic activities that can bring abundant information as well as crucial materials to improve the innovation ability of the corporations. Therefore, corporations should deepen cooperation with all aspects on every production link such as product development, designing, production, sales and services. As with social capital, market orientation of strategy is also absolutely necessary for corporations. There is now a general consensus that market-oriented economic order is the only viable option for modern societies. For this reason, corporations 
have always insisted on the concept of market-orientation. Faced with the complex and multitransferring circumstances, organizational learning is a main method for corporations to obtain the competitive advantage. However, the factors that govern the service innovation performance have yet to be fully defined. So, would corporate social capital and market orientation have a positive impact on service innovation performance significantly? The view shows us a new way to study service innovation performance.

However, compelling evidence in this regard is currently lacking. Previous studies mostly concentrated on manufacturing, rarely involved in service innovation performance, let alone the relationship between corporate social capital, market orientation and organizational learning. The study proposes an integrated model concerning corporate social capital, market orientation, organizational learning and service innovation performance in the context of China's economic transformation.

\section{Theoretical Background and Hypotheses}

\subsection{Service Innovation Performance}

International economic globalization has brought continuous pressure on enterprises to constantly create new products and services. Enterprises have found service innovation to be an indispensable element of survival and have tried to become service-oriented. Globally, services account for over $60 \%$ of the economies of Brazil, Russia, Japan and Germany, and the service sector is growing rapidly in the emerging economies of India and China.

It is noteworthy that service innovation is becoming more and more crucial for the economies of developing countries. Without exception, services are now a larger percentage of GDP than manufacturing in all nations for which the World Bank maintains statistics (Metter \& Marucheck, 2007). This transformation process of national economies is driven by the growth of the service sector itself. Service innovations are ubiquitous and their role in creating economic growth and well being is increasingly acknowledged (Gallouj, 2002). This is also mirrored in the extensive literature on service management, service marketing and service innovation, and by the rise of the service dominant logic perspective (e.g., Michel, Brown \& Gallan, 2008; Vargo \& Lusch, 2004; Lusch, Vargo \& Wessels, 2008) and widespread deliberations on a comprehensive service science.

The initial view of service innovation is attributed to Schumpeter. Generally speaking, as an intangible activities of enterprises, service innovation uses a variety of innovative ways to meet customers' needs and maintains competitive advantages which is formed in the process of service. Customers can be provided with two types of new solutions by service innovation. The first combines new concepts or subjects to constitute new solutions, and resolves into 
improvement innovation and fundamental innovation. The other involves solving the same challenge with greater efficiency, and can cover the enhancement of productivity, suitability, or quality (Gadrey, Gallouj \& Weinstein, 1995). Actually, practitioners prefer to measure service innovation from the point of financial or quantifiable indicators to master the specific indexes. Different scholars present distinct views on the issue of the measurement of service innovation performance. This paper references the most representative view of process and results performance measurement by Voss, Johnston, Silvestro, Fitzgerald and Brignall (1992), which is described as Table 1.

Fizgerald, Johnston, Silvestro, Brignall and Voss (1991) found that service innovation performance is multi-dimensional, not only reflects the effectiveness of the company's operations and the competition of the market, but also a project plan, or the level of the overall development process. Storey and Kelly (2001) borrowed the concept of the Balanced Scorecard, and divided the metrics of service innovation performance into the individual project level and the overall program level.

\begin{tabular}{|c|c|l|}
\hline \multirow{4}{*}{$\begin{array}{c}\text { Process } \\
\text { performance }\end{array}$} & Standard costs & $\begin{array}{l}\text { The average cost of developing each service product, sales } \\
\text { distribution, or the ratio of new service developments. }\end{array}$ \\
\cline { 2 - 3 } & Effectiveness & $\begin{array}{l}\text { The number of new service products developed annually and the } \\
\text { costs of new services. }\end{array}$ \\
\cline { 2 - 3 } $\begin{array}{c}\text { Result } \\
\text { performance }\end{array}$ & Financial issues & $\begin{array}{l}\text { Time of service investment, time to develop new service models, } \\
\text { time from development of new service models to entry, and time } \\
\text { needed for clients of the company to apply the new concepts. }\end{array}$ \\
\cline { 2 - 3 } & Competitiveness & $\begin{array}{l}\text { Yield rate, lowering of costs, and achievement of cost efficiency. } \\
\text { Exceeding the originally established market share, sales, and } \\
\text { growth targets, and giving competitive advantages important to } \\
\text { the company. }\end{array}$ \\
\cline { 2 - 3 } & Quality & $\begin{array}{l}\text { Service quality and experience better than those of competitors, } \\
\text { greater reliability, and more user friendly. }\end{array}$ \\
\hline
\end{tabular}

Table 1. The Measurement of Service Innovation Performance

\subsection{Corporate Social Capital \& Service Innovation Performance}

Bourdieu's (1986) analysis was identified as the first integrated analysis of social capital by Portes (1998). Bourdieu defined the concept as the gathering of the actual or potential resources which were connected with the possession of a continuous network of relationships of mutual acquaintance or recognition. Some famous scholars such as Coleman (1988) pointed out that social capital means privileged access to knowledge and information, or some opportunities for new business, reputation and influence from the perspective of organization. However, despite the notion has been accepted widely, there remains widespread uncertainty about its meanings (Koka \& Prescott, 2002). In general, scholars divided social capital into two types: personal benefits on career advancement from social network theorists (e.g. Burt, 1997) and public good (e.g., Bourdieu, 1986; Coleman 1988; Putnam, 1993). Social capital 
could benefit not only those who create it but also group members at large in the sense of public level. (Kostova \& Roth, 2003).

Corporate social capital has got remarkable attention of practitioners and scholars from different backgrounds lately. Compared with physical capital or human capital, corporate social capital refers to a specific and essential asset in contemporary business world that yields a stream of benefits. Corporate social capital is defined as networks of social relations existing within a corporation or resource embedded in social networks by which a company has access to activate material and virtual resources (e.g., Bourdieu, 1986; Nahapiet \& Ghoshal, 1998; Leana \& Van Buren, 1999; Gargiulo \& Benassi, 2000; Lin, 2001; Oh, Labianca \& Chung, 2006). Network theories highlight the importance of information sharing, social cohesion and mutual goals that constitute social capital (Borg, Toikka \& Primmer, 2014).

Corporate social capital enables efficient contracts and has many positive impacts on service innovation performance. On the one hand, strong links between organizations help getting more information, shorten the corporate product development time and costs (Adler \& Kwon, 2002). On the other hand, social network accelerates innovation. In the industry cluster, the vertical relationship of social capital, including upstream suppliers and downstream customers and end users provide strategic guidance for corporations to improve their supply chains and business operations; Lateral relationship of social capital, including fellow competitors and other related businesses can provide important information for the enterprise market; Social relationship capital, such as governments, intermediary, financial and investment institutions can provide professional technical, personnel and financial support. Doong, Fung and $\mathrm{Wu}$ (2010) proposed that the strength of the relationship between the corporate networks effected by corporate social capital has a positive impact on corporation value. Steinfield, Scupola and López-Nicolás (2010) thought that social capital also has a significant impact on business performance. Thus, we propose that well-developed mechanism of corporate social capital can enhance innovation practices. We suggest the following hypothesis:

H1: Corporate social capital has a positive impact on service innovation performance.

\subsection{Market Orientation \& Service Innovation Performance}

Market orientation is one of the most significant methods to strategic management as well as the core of the marketing literature. It is considered as the organizational culture which concentrates on the performance. Market knowledge and information play an important role in getting competitive advantage (Narver \& Slater, 1990). Market orientation means the true understanding of customers' demands, and adopting the true process to be responsiveness to the development of the market. In the beginning of the 1990s, market orientation framework was recognized and introduced (Sheppard, 2011; Day, 1994). Some researchers equal market 
orientation to the marketing concept (Shapiro, 1988; Webster, 1988). It is clear that there is no shortage of controversy. Narver and Slater (1990) indicated that market orientation is the coordinated application of inter-functional resources and the business culture that efficiently creates superior value for customers. Kohli and Jaworski (1990) maintained that market orientation is the ability of the organization to generate superior information about customers and competitors. Day (1994) thought that the marketing capabilities should be executed in organization better than ever to meet the requirement of market orientation. Grasping the market opportunities, maintaining good relations with customers, getting feedback about their needs and subsequently providing them with better service, looking for the technology and continuing product improvement is essential to improve the marketing capabilities. Cervera, Molla and Sánchez (2001) classified market orientation into four approaches: culturalphilosophical, orientations based on the customers and competitors, inter-segment cooperation, market data processing, and sources and capabilities theories.

Some market-driven innovation can improve the level of products. However, some other studies have shown that market-oriented enterprises will lead to too much focus on the market, which ignore the law of development of the market itself. Actually, Market orientation part of the corporate strategy orientation is able to guarantee the strategic level and the implementation level of consistency. Companies can form a complementary use of existing resources and promote organizational performance on the basis of the two works). Many researchers have proved that market orientation has a positive relationship with performance. Siguaw, Brown and Widing (1994) and Piercy, Cravens and Lane (2009) insisted that a marketoriented firm would make a difference to their sales behavior and performance. Besides, a majority of scholars revealed that market orientation was positively related to performance through moderating or mediating effects. Han, Kim and Srivastava (1998) found that market orientation makes an important contribution to performance through innovations. Mavondo and Farrell (2003) proposed that the relationship between market orientation and performance is mediated by marketing implementation. Taylor, Kim, Ko, Park, Kim and Moon (2008) noted that sales staff with market orientation would lead to higher relationship commitment and improve business performance. Based on the previous studies, we propose:

H2: Market orientation has a positive impact on service innovation performance.

\subsection{Organizational Learning \& Service Innovation Performance}

Organizational learning is a token of mutual exchange belief, reflecting shareholders' cognition of needs and expectations, and influencing the interaction of both parties ( $\mathrm{Li}, 2006)$. Exploitative learning and exploratory learning are two different dimensions of organizational learning (March, 1991). Based on the existing studies, exploitative learning uses the available stakeholders' information to build on its skills. It is evident that exploitative learning could 
master the knowledge better from existing consumers to improve the practice of the organization. On the contrary, exploratory learning absorbs new knowledge from outside the range of customers and competitors. The organization should acquire multitudinous information which is different from existing knowledge and skills. Most notably, exploratory learning expands a variety of new knowledge on the foundation of greater opportunities. In view of the different implications of two learning style, obviously, they may have different impacts on service innovation performance. Exploitative learning does help in promoting the quality of the products and services through full exchanges with consumers and competitors. Meanwhile, exploratory learning could absorb more foreign technology to provide new solutions for service innovation performance. The importance of organizational learning for enterprises is on the basis of the criticality of knowledge to obtain competitive advantages (Grant, 1996). Both exploitative learning and exploratory learning are essential to the survival and the development of the organization. Hence, we suggest the following hypothesis:

H3: Organizational learning has a positive impact on service innovation performance.

\subsection{Corporate Social Capital \& Organizational Learning}

Corporate social capital facilitates inter-unit resource exchanges and product innovation (Gabbay \& Zuckerman, 1998). As one of the two main modes of organizational learning, exploratory learning represents the capability of an organization to learn through questioning, pushing the knowledge frontier, and being proactive and willing to take risks (Andersson \& Linderoth, 2008). Therefore, social capital provides favorable conditions for exploratory learning. Meanwhile, corporate social capital promotes entrepreneurship (Chong \& Gibbons, 1997), strengthens supplier relations (Uzzi, 1997) and the formation of start-up companies (Walker, Kogut \& Shan, 1997). Unlike exploratory learning, exploitative learning involves the extension of the existing capabilities. In a similar way, these characteristics of corporate social capital can be beneficial to exploitative learning. In general, corporate social capital in organizations lays the foundation of information sources of organizational learning. It is safe to say, in fact, corporate social capital and organizational learning stimulate one another for common development, but these mutually reinforcing relationships behave differently in the stages of development. Based on this, we propose the following assumption:

H4: Corporate social capital has a positive impact on organizational learning.

\subsection{Market Orientation \& Organizational Learning}

Market orientation is a major source of the competitive advantages which involves gathering intelligence about consumers, competitors and channels. It is also claimed that market 
orientation provides an additional strategic dimension and a proper means to understanding markets. Firms using market orientation perform better because they understand their customers, rivals and channels better (Hult \& Ketchen, 2001). Market orientation can result in better customer relationship which can enhance performance outcomes like sales, growth (Crosby, Evans \& Cowles, 1990). As a consequence, market orientation provides an excellent pathway to the implementation of organizational learning. It is necessary for procedural learning, empirical learning, and creative learning to establish market orientation (Slater \& Narver, 1995). Therefore, we can deduce:

H5: Market orientation has a positive impact on organizational learning.

\subsection{The Intermediary Role of Organizational Learning}

Organizational learning is a process of absorbing new knowledge and information to improve enterprises' behavior (Crossan, Lane, White \& Djurfeldt, 1995). Senge (1990) held that members' learning was an effective method to unite and create knowledge. Tran (2008) pointed out that good organizational learning environment could stimulate more innovation, which had become the main process of the enterprises to improve innovation capability. Generally speaking, the performance of enterprises that assembles knowledge resources through effective learning is better than those who do not in an unstable environment. Morgan and Berthon's (2008) research showed that knowledge exchange affects innovation performance through knowledge creation and organizational learning. Therefore, we make the following assumptions:

H6: Organizational learning partially mediates the relationship between corporate social capital, market orientation and service innovation performance.

Based on those literatures analysis, we propose these two hypotheses.

H7: Organizational learning mediates the impact of corporate social capital on service innovation performance.

H8: Organizational learning mediates the impact of market orientation on service innovation performance. 
Based on the above hypotheses, we propose research framework shown in Figure 1.

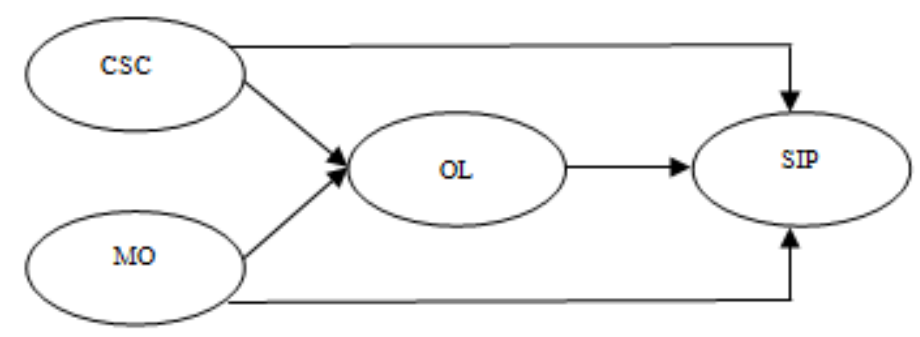

Figure 1. Research framework

\section{Research Design}

\subsection{Samples \& Data Collection}

Whereas prior studies examined the SIP and its influencing factors through interviews, case studies, this study tested the theoretical model and the proposed hypotheses through the questionnaire. The structured questionnaire was created on the basis of academic oriented literature. All constructs were measured with multiple-item scales. All of the items were formed in a five-point Likert scale ranging from "strongly disagree" to "strongly agree". The questionnaire comprising multiple items was administered to chief technology officers, marketing managers and product managers of the firms in Pearl River Delta of China. The selected managers or officers should have relevant experiences in these areas. These people were chosen because they are more likely to have a relatively clear vision of corporate social capital and market orientation, also have a good understanding of service innovation performance. They're more likely to approve of organizational learning. The data they provided may be more reliable and objective. Besides, the questionnaire was patterned after those of prior studies on corporate social capital, market orientation, organizational learning, and service innovation performance.

Afterward, the questionnaire was further pretested with 30 high-tech enterprises. Items that identified as being problematic were revised or eliminated. The research modified the questionnaire through the detection of internal consistency quotient of the questionnaire's subjects, single subject reliability analysis and KMO value. From July to September 2013, we distributed 550 questionnaires through MBA classroom, e-mail, posting and face to face interview. Responses from 208 firms were received 20 days later. Telephone calls were regularly made to the respondents that didn't reply to the questionnaire. At last, we received 434 questionnaires, with a total recovery rate of $81.8 \%$. Hence, Valid questionnaires are 230 and the final effective rate is $41.8 \%$. 
We compared the early and late respondents to check non-response bias. The first samples were classified as early $(n=208)$, while the follow-up contacts were considered late $(n=226)$. The independent sample $T$ tests showed no statistically significant difference between the two groups. Besides, we used Harmon's one-factor test to check common-method bias to the data. The result revealed that a single factor did not emerge.

The structure of the sample firms is sufficiently diverse and heterogeneous:

- Industry categories: $28.8 \%$ in scientific and technology services, $21.9 \%$ in the finance and insurance industry, $16.3 \%$ in the culture, sports and leisure industry, $14.0 \%$ in wholesale and retail, $9.8 \%$ in communicating services and $9.2 \%$ in logistics, transportation and warehousing services;

- Founded time: less than 3 years accounted for $9.5 \%, 4$ to 6 years accounted for $10.8 \%$, 7 to 9 years accounted for $12.2 \%, 10$ to 20 years accounted for $38.6 \%, 20$ to 30 years accounted for $14.9 \%, 30$ to 45 years accounted for $6.6 \%$, more than 50 years accounted for $7.4 \%$;

- Number of employees: $33.3 \%$ have less than 100 employees, $11.1 \%$ have 101 to 200 employees, $15.2 \%$ have 201 to 500 employees, 9.5\% have 501 to 1000 employees, and $30.9 \%$ have more than 1000 employees.

\subsection{Measures}

The measurement scale of corporate social capital is mainly according to Chen and Li (2011), which is made up of 3 constructs, including longitudinal relation capital, horizontal relationship capital, and social relationship capital. Market orientation was on the basis of analyzing and sorting the previous viewpoints, which consisted of 3 items including the generation of market information, the spread of market information and the market information response. The scale of measuring organizational learning is based on March (1991), which is made up of exploitative learning and exploring learning. Service innovation performance makes reference to the studies of Voss et al. (1992), Storey and Kelly (2001) which consists of process performance and result performance. We controlled for firm age, size, and capital in our model, as these variables reflect a firm's resources and market power to exploit existing competencies. 


\section{Results and Discussion}

\subsection{Measurement Properties}

This research uses the coefficient of Cronbach's alpha to examine the reliability of each factor or variable. Results show that the Cronbach's alpha of each factor belongs to an acceptable scope (higher than 0.7 ), and thus demonstrates the scales we use have good reliability. Factor analysis was used to check for convergent and discriminant validity. All items of a scale should load strongly on a single factor to demonstrate convergent validity and load weakly on other factors to demonstrate discriminant validity. The results of the factor analysis provide evidence of both convergent and discriminant validity.

We use exploratory factor analysis (EFA) and confirmatory factor analysis (CFA) to examine the construct validity and content validity of measurement tools to analyze exploratory factors. Results show that the KMO values of the corporate social capital, market orientation, organizational learning and service innovation performance is $0.721,0.829,0.801$ and 0.717 respectively. It is obvious that the indicators have reached an acceptable level in general. Therefore, the initial sample of this study has good construct validity. Bartlett sphericity test shows the significance probability is $0.000(* * *)$, indicating that next step of factor analysis can be continued.

\subsection{Statistical Description and Variables Correlations}

We investigate correlation of the variables to reveal the strength of the statistical relationships between variables after the construct validity analysis of the scales. The means, standard deviations, correlations used in the study are shown in Table 2.

\begin{tabular}{|c|c|c|c|c|c|c|c|c|c|}
\hline & Mean & SD & 1 & 2 & 3 & 4 & 5 & 6 & 7 \\
\hline LRC & 3.663 & .629 & & & & & & & \\
\hline HRC & 3.587 & .692 & $.248^{* *}$ & - & & & & & \\
\hline SRC & 3.602 & .625 & $.301 * *$ & $.416 * *$ & - & & & & \\
\hline ETL & 3.653 & .508 & $.312 * *$ & $.468 * *$ & $.380 * *$ & - & & & \\
\hline ERL & 3.65 & .602 & $.337 * *$ & $.334 * *$ & $.379 * *$ & $.398^{* *}$ & - & & \\
\hline PP & 3.563 & .683 & $.236 * *$ & $.234 * *$ & $.272 * *$ & $.381 * *$ & $.288^{* *}$ & - & \\
\hline RP & 3.310 & .672 & $.256 * *$ & $.220 * *$ & $.278 * *$ & $.378 * *$ & $.319 * *$ & $.379 * * *$ & - \\
\hline GMI & 3.65 & .716 & - & & & & & & \\
\hline SMI & 3.62 & .811 & $.230 * *$ & 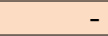 & & & & & \\
\hline MIR & 3.47 & .635 & $.380 * *$ & $.291 * *$ & - & & & & \\
\hline ETL & 3.65 & .602 & $.378 * *$ & $.355^{* *}$ & $.423 * *$ & - & & & \\
\hline ERL & 3.65 & .491 & $.332 * *$ & $.334 * *$ & $.353^{* *}$ & $.398^{* *}$ & - & & \\
\hline PP & 3.56 & .683 & $.281 * *$ & $.248 * *$ & $.283 * *$ & $.381 * *$ & $.288^{* *}$ & - & \\
\hline $\mathbf{R P}$ & 3.31 & .672 & $.230 * *$ & $.292 * *$ & $.207 * *$ & $.378 * *$ & $.319 * *$ & $.379 * * *$ & - \\
\hline
\end{tabular}

Note: LRC-longitudinal relation capital; HRC-horizontal relationship capital; SRC-social relationship capital; GMI-the generation of market information; SMI-the spread of market information; MIR-market information response; ETL-exploitative learning; ERL-exploring learning; PP-process performance; RPresult performance. $* * * \mathrm{p}<0.001, * * \mathrm{p}<0.01, * \mathrm{p}<0.05$.

Table 2. Correlations Matrix for Constructs 


\subsection{Test of Multi-Hypothesis of Structural Model}

This study designed the structural equation model on the basis of the literatures and hypotheses between corporate social capital, market orientation, organizational learning and service innovation performance. Market orientation and corporate social capital are exogenous variables and service innovation performance is potential endogenous variables. As shown in Table 3, in the integrated model, $X 2 / d f$ is 2.044 (less than 5), RMR value is 0.049 (less than 0.05 ), RMSEA is 0.068 (less than 0.1 ), CFI value is 0.885 , GFI value is 0.911 (more than 0.80). All the values meet the evaluation criteria. Therefore, the goodness-of-fit index of the model is relatively good, and the model does not have to be modified.

\begin{tabular}{|l|r|r|r|r|r|r|}
\hline Fitness indexes & \multicolumn{1}{|c|}{ X2/df } & \multicolumn{1}{|c|}{ RMR } & \multicolumn{1}{c|}{ CFI } & \multicolumn{1}{c|}{ GFI } & \multicolumn{1}{c|}{ RMSEA } & \multicolumn{1}{c|}{ AIC } \\
\hline Default model & 2.044 & 0.049 & 0.885 & 0.911 & 0.068 & 306.292 \\
\hline Saturated model & - & 0.000 & 1.000 & 1.000 & - & 325.000 \\
\hline Independence model & 8.126 & 0.147 & 0.000 & 0.424 & 0.176 & 539.160 \\
\hline
\end{tabular}

Table 3. The Fitness Index of the Integrated Model

Table 4 shows that the parameter estimates within variables pass the test totally in the integrated model. The fully standardized effect's value of the corporate social capital and service innovation performance is $0.263(P<0.001)$, and basically goes through the test of significance. The fully standardized effect's value of the market orientation and service innovation performance is $0.304(P<0.001)$. The fully standardized effect's value of the exploitative learning, exploring learning and service innovation performance is $0.375,0.344$. The fully standardized effect's value of the exploitative learning, exploring learning and corporate social capital is 0.589 and 0.496 . The fully standardized effect's value of the exploitative learning, exploring learning and market orientation is 0.527 and 0.446 .

\begin{tabular}{|c|r|r|r|r|r|}
\hline Path & Estimate & Standard & S.E. & C.R. & P \\
\hline SIPßCSC & .289 & .263 & .137 & 4.806 & $* * *$ \\
\hline SIPBMO & .297 & .304 & .140 & 4.553 & $* * *$ \\
\hline ETLBCSC & .622 & .589 & .134 & 4.624 & $* * *$ \\
\hline ERLB CSC & .452 & .496 & .108 & 4.167 & $* *$ \\
\hline ETLBMO & .497 & .527 & .104 & 4.806 & $* * *$ \\
\hline ERLBMO & .665 & .446 & .144 & 3.816 & $* * *$ \\
\hline SIPBETL & .288 & .375 & .134 & 4.325 & $* *$ \\
\hline SIPBERL & .358 & .344 & .142 & 4.549 & $* * *$ \\
\hline ERLBETL & .092 & .133 & .127 & 2.025 & NS \\
\hline
\end{tabular}

Note: NS-No Significant.

Table 4. Path Efficiencies of Variables

As $\mathrm{H} 1, \mathrm{H} 3$ and $\mathrm{H} 4$ are supported, the mediating effect of organizational learning between corporate social capital and service innovation performance has been verified. Besides, after the introduction of mediator, the path coefficient has reduced. That is to say, organizational 
learning partly mediates the effect of corporate social capital on service innovation performance. Likewise, organizational learning plays a partly mediating role in the relationship between market orientation and service innovation performance. All the hypotheses were supported.

\section{Conclusions}

The study addresses a central question in the service innovation field regarding corporate social capital, market orientation, organizational learning and service innovation performance. Based on 230 samples from the service industries in Pearl River Delta of China, we have gained some valuable findings:

- corporate social capital, market orientation and organizational learning has a positive effect on service innovation performance,

- corporate social capital, market orientation has a positive effect on organizational learning, and

- organizational learning plays a mediating role between corporate social capital, market orientation and service innovation performance.

\subsection{Implications for Research}

This paper makes some contributions to the literature. Drawing on prior studies, the extended issues related to service innovation have not been sufficiently studied. Most prior researches have focused on case studies or performed theoretical analysis to explore service innovation. Few have empirically tested a model with field research. With corporate social capital, market orientation, and organizational learning, this study lends explanation to the performance of service innovation and the interdependence between them. It may serve as a template for researchers investigating those issues.

Firstly, social capital has a positive impact on service innovation performance, indicating that companies should have a clear understanding of the current stage of the development according to their own social capital. It is usually postulated that a reasonable measure of required capital and the optimization of resources are essential. The view that companies should try to integrate information and technology to improve their diversified development ability and innovation ability both in vertical value chains or networks is consistent with the previous studies. Moreover, the point that compared to the vertical relationship, the horizontal 
relationship capital is at a higher level which can offer necessary knowledge and information that can be explained by the theory of open innovation.

Secondly, the view of market orientation has similarity and difference with previous studies. Some scholars believe that there is no direct impact on market orientation and organizational performance. However, in the multi-structural model assumptions, the degree of market orientation and service innovation performance is positively correlated. This is because with the market economy and the increasingly fierce global competition, companies have increasingly recognized the role of the market guidance at the strategic level. Therefore, many companies have elevated the market orientation to the height of strategy, grasping all aspects links of the market orientation, establishing and improving the implementation of marketoriented mechanism to improve business performance. It's an important means to obtain longterm development of the competition for the enterprises at the critical juncture of the economic transformation.

Thirdly, this paper shows that social capital, market orientation has a positive impact on organizational learning. Organizational learning is a vital activity in order to gain knowledge and improve strength. Social capital as a key access to information and resources has determined the content of the company's future learning. Enterprises should build a network to upgrade existing social capital with users, vendors, the external institutions, and even competitors to share knowledge and exchange information. Some scholars believe that the market itself will promote organizational learning as a learning-oriented behavior. The similarities above have gradually been reflected in the study and previous studies, but no researchers have elevated social capital and market-oriented research into the strategic level to explore the relationship between the two and organizational learning so far.

Lastly, the demonstration on mediating effect of organizational learning sheds new light on the relationship between corporate social capital, market orientation and service innovation performance. The view that organizational learning has a positive effect on competitiveness has been widely accepted. However, this paper point out that corporate social capital and market orientation could improve the service innovation performance though exploitative learning and exploring learning in the social network, which is also one of the contributions of this study.

\subsection{Implications for Practice}

This study also has significant implications to enterprises. With the innovation being the main source for competitive advantage, managers began to realize the importance of service innovation in the increasingly fierce competition. The results of this study suggest that enterprises should establish the social networks accommodated by the development of 
organization. In addition, more attention should be paid to focus on market orientation to enhance the ability to respond to changes in the market environment. It's particularly necessary to strengthen organizational learning to improve the ability to information and the ability to innovate. In other words, enterprises should not only take cognizance of the significance of market orientation between enterprises in strategic perspective, but also take actions in organizational learning between the social networks.

\subsection{Limitations and Future Research}

Although this study provides valuable insights, some potential limitations should be recognized. First of all, the research object of this paper is limited to the enterprises in Pearl River Delta of China, the universality of the results should be further verified in other regions or areas. Secondly, all variables and theories all come from western research, which is not adequate in explaining some results in the context of China. Therefore, future research may control variables such as culture and distance. Moreover, given the limited theoretical and empirical research to service innovation, future research studies might widen their examination to include other potential factors.

\section{Acknowledgments}

This research is supported by the National Natural Science Foundation of China (71272132; 71090403/71090400) \& the Fundamental Research Funds for the Central Universities (2014ZDXMPY02).

\section{References}

Adler, P., \& Kwon, S. (2002). Social capital: prospects for a new concept. Academy of Management Review, 27(1), 17-40. http://dx.doi.org/10.2307/4134367

Andersson, A., \& Linderoth, H.C.J. (2008). Learn not to learn-A way of keeping budgets and deadlines in ERP projects. Enterprise Information Systems, 2(1), 77-95. http://dx.doi.org/10.1080/17517570701793830

Bourdieu, P. (1986). The Forms of Capital. In J. Richardson (Ed.). Handbook of Theory and Research for the Sociology of Education. New York: Greenwood Press. 
Borg, R., Toikka, A., \& Primmer, E. (2014). Social capital and governance: a social network analysis of forest biodiversity collaboration in central Finland. Forest Policy and Economics, 6, 1-8.

Burt, R.S. (1997). The contingent value of social capital. Administrative Science Quarterly, 42, 339-365. http://dx.doi.org/10.2307/2393923

Cervera, A., Molla, A., \& Sánchez, M. (2001). Antecedents and consequences of market orientation in public organizations. European Journal of Marketing, 35(11), 1259-1288. http://dx.doi.org/10.1108/EUM0000000006476

Chesbrough, H.W. (2003). The era of open innovation. MIT Sloan Management Review, 44(3), 35-41. available online in: http://sloanreview.mit.edu/article/the-era-of-open-innovation/

Chen, J., \& Li, F.Y. (2011). Corporate social capital: sociological interpretation of technological innovation. Scientific Studies, 19(3), 102-107.

Chong, L., \& Gibbons, P. (1997). Corporate entrepreneurship: The roles of ideology and social capital. Group and Organization Management, 22, 10-30.

http://dx.doi.org/10.1177/1059601197221004

Coleman, J.S. (1988). Social capital in the creation of human capital. American Journal of Sociology, 94, 95-120. http://dx.doi.org/10.1086/228943

Crosby, L.A., Evans, K.R., \& Cowles, D. (1990). Relationship quality in services selling: An interpersonal influence perspective. The Journal of Marketing, 54(3), 68-81. http://dx.doi.org/10.2307/1251817

Crossan, M.M., Lane, H.M., White, R.E., \& Djurfeldt, L. (1995). Organizational learning: Dimensions for a theory. The International Journal of Organizational Analysis, 3(4), 337-360. http://dx.doi.org/10.1108/eb028835

Day, G. (1994). Misconceptions about market orientation. Journal of Market Focused Management, 4, 5-16. http://dx.doi.org/10.1023/A:1009882027377

Doong, S.C., Fung, H.G., \& Wu, J.Y. (2010). Are social, financial, and human capital value enhancing? Evidence from Taiwanese firms. International Review of Economics and Finance, 20(3), 395-405. http://dx.doi.org/10.1016/j.iref.2010.11.018

Fizgerald, L., Johnston, R., Silvestro, R., Brignall, T.J., \& Voss, C. (1991). Performance measurement in service business. London: CIMA.

Gabbay, S.M., \& Zuckerman, E.W. (1998). Social capital and opportunity in corporate R\&D: The contingent effect of contact density on mobility expectations. Social Science Research, 27, 189-217. http://dx.doi.org/10.1006/ssre.1998.0620 
Gadrey, J., Gallouj, F., \& Weinstein, O. (1995). New modes of innovation: how service benefit industry. International Journal of Service Industry Management, 6(3), 4-16.

http://dx.doi.org/10.1108/09564239510091321

Gallouj, F. (2002). Innovation in the service economy: the new wealth of nations. Cheltenham: Edward Elgar. http://dx.doi.org/10.4337/9781843765370

Gargiulo, M., \& Benassi, M. (2000). Trapped in your own net? Network cohesion, structural holes and the adaptation of social capital. Organization Science, 11(2), 183-196. http://dx.doi.org/10.1287/orsc.11.2.183.12514

Grant, R.M., (1996). Toward a knowledge-based theory of the firm. Strategic Management Journal, 17(Winter Special Issue), 109-122. http://dx.doi.org/10.1002/smj.4250171110

Han, J.K., Kim, N., \& Srivastava, R. (1998). Market orientation and organizational performance: is innovation a missing link?. Journal of Marketing, 62(4), 30-45. http://dx.doi.org/10.2307/1252285

Hult, G.T.M., \& Ketchen, D.J. (2001). Does market orientation matter? A test of the relationship between positional advantage and performance. Strategic Management Journal, 22(9), 899-906. http://dx.doi.org/10.1002/smj.197

Kohli, A.K., \& Jaworski, B.J. (1990). Market orientation: the construct, research propositions, and managerial implications. Journal of Marketing, 54, 1-18. http://dx.doi.org/10.2307/1251866

Koka, B.R., \& Prescott, J.E. (2002). Strategic alliances as social capital: a multidimensional view. Strategic Management Journal, 23: 795-816. http://dx.doi.org/10.1002/smj.252

Kostova, T., \& Roth, K. (2003). Social capital in multinational corporations and a micro-macro model of its formation. Academy of Management Review, 8, 297-317. http://dx.doi.org/10.2307/30040714

Leana, C.R., \& Van Buren III, H.J. (1999). Organizational social capital and employment practices. Academy of Management Review, 24(3), 538-555. http://dx.doi.org/10.2307/259141

Li, L.Y. (2006). Relationship learning at trades shows: its antecedents and consequences. Industrial Marketing Management, 35(2), 166-177. http://dx.doi.org/10.1016/j.indmarman.2005.03.006

Lin, N. (2001). Social capital: A theory of social structure and action. Cambridge: Cambridge University Press. http://dx.doi.org/10.1017/СBO9780511815447

Lusch, R.F., Vargo, S.L., \& Wessels, G. (2008). Towards a conceptual foundation for service science: contributions from service dominant logic. IBM Systems Journal, 47(1), 5-14. http://dx.doi.org/10.1147/sj.471.0005 
March, J.G. (1991) Exploration and exploitation in organizational learning. Organization Science, 2(1), 71-87. http://dx.doi.org/10.1287/orsc.2.1.71

Mavondo, F.T., \& Farrell, M.A. (2003). Cultural orientation: its relationship with market orientation, innovation and organizational performance. Management Decision, 41(3), 241-249. http://dx.doi.org/10.1108/00251740310468054

Metter, R., \& Marucheck, A. (2007). Service management-academic issues and scholarly reflections from operations management researchers. Decision Science, 38(2), 195-215. http://dx.doi.org/10.1111/j.1540-5915.2007.00156.x

Michel, S., Brown, S.W., \& Gallan, A.S. (2008). Service logic innovations: How to innovate customers, not products. California Management Review, 5(3), 49-65. http://dx.doi.org/10.2307/41166445

Morgan, R.E., \& Berthon, P. (2008). Market orientation, generative learning, innovation strategy and business performance inter-relationships in bioscience firms. Journal of Management Studies, 45(8), 1329-1353. http://dx.doi.org/10.1111/j.1467-6486.2008.00778.x

Nahapiet, J., \& Ghoshal, S. (1998). Social capital, intellectual capital and the organizational advantage. Academy of Management Review, 23(2), 242-266. http://dx.doi.org/10.2307/259373

Narver, J., \& Slater, S. (1990). The effect of a market orientation on business profitability. Journal of Marketing, 54, 20-35. http://dx.doi.org/10.2307/1251757

Oh, H., Labianca, G., \& Chung, M.H. (2006). A multilevel model of group social capital. Academy of Management Review, 31(3), 569-582. http://dx.doi.org/10.5465/AMR.2006.21318918

Piercy, N.F., Cravens, D.W., \& Lane, N. (2009). Sales management control level and competencies: Antecedents and consequences. Industrial Marketing Management, 38(4), 459-467. http://dx.doi.org/10.1016/j.indmarman.2008.03.002

Portes, A. (1998). Social capital: its origin and applications in modern sociology. Annual Review of Sociology, 24, 1-24. http://dx.doi.org/10.1146/annurev.soc.24.1.1

Putnam, R.D. (1993). The prosperous community: social capital and public life. American Prospect, 13, 35-42.

Senge, P.M. (1990). The fifth discipline: The art and practice of the learning organization. New York: Doubleday Currency.

Shapiro, B.P. (1988). What The Hell is Market Oriented?. Harvard Business Review, 66(6), 119-125. 
Sheppard, H. (2011). The evolution and conceptualization of market orientation: what managers ought to know. Journal of Management Policy and Practice, 12(6), 30-45.

Siguaw, J.A., Brown, G., \& Widing, R.E. (1994). The influence of the market orientation of the firm on sales force behavior and attitudes. Journal of Marketing Research, 31(1), 106-116. http://dx.doi.org/10.2307/3151950

Slater, S., \& Narver, J. (1995). Market orientation and the learning organization. Journal of Marketing, 59(3), 63-74. http://dx.doi.org/10.2307/1252120

Steinfield, C., Scupola, A., \& López-Nicolás, C. (2010). Social capital, ICT use and company performance: findings from the medicon valley biotech cluster. Technological Forecasting \& Social Change, 77(7), 1156-1166. http://dx.doi.org/10.1016/j.techfore.2010.03.004

Storey, C., \& Kelly, D. (2001). Measuring the performance of new service development activities. The Service Industries Journal, 21(2), 71-90. http://dx.doi.org/10.1080/714005018

Taylor, C.R., Kim, K.H., Ko, E., Park, M.H., Kim, D.R., \& Moon, H.I. (2008). Does having a market orientation lead to higher levels of relationship commitment and business performance? Evidence from the Korean robotics industry. Industrial Marketing Management, 37(7), 825-832. http://dx.doi.org/10.1016/j.indmarman.2008.03.006

Tran, T.A. (2008). A Conceptual model of learning culture and innovation schema. Competition Review, 18(3), 287-299. http://dx.doi.org/10.1108/10595420810906046

Uzzi, B. (1997). Social structure and competition in interfirm networks: the paradox of embeddedness. Administrative Science Quarterly, 42, 35-67. http://dx.doi.org/10.2307/2393808

Vargo, S.L., \& Lusch, R.F. (2004). Evolving to a new dominant logic for marketing. Journal of Marketing, 68(1), 1-17. http://dx.doi.org/10.1509/jmkg.68.1.1.24036

Voss, C., Johnston, R., Silvestro, R., Fitzgerald, L., \& Brignall, T. (1992). Measurement of innovation and design performance in services. Design Management Journal, 3(1), 40-46.

Walker, G., Kogut, B., \& Shan, W. (1997). Social capital, structural holes and the formation of an industry network. Organization Science, 8, 109-125. http://dx.doi.org/10.1287/orsc.8.2.109

Webster, F.E. (1988). Rediscovering the marketing concept. Business Horizons, 31, 29-39. http://dx.doi.org/10.1016/0007-6813(88)90006-7

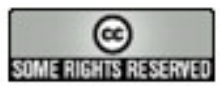

Article's contents are provided on a Attribution-Non Commercial 3.0 Creative commons license. Readers are allowed to copy, distribute and communicate article's contents, provided the author's and Journal of Industrial Engineering and Management's names are included. It must not be used for commercial purposes. To see the complete license contents, please visit http://creativecommons.org/licenses/by-nc/3.0/. 